\title{
KEY ACTORS IN DKI JAKARTA ENTREPRENEURIAL DEVELOPMENT MODEL WITH THE INTREPRETATIVE STRUCTURAL MODELING (ISM) APPROACH
}

\author{
Asep Taryana $\left.{ }^{*}\right)$, Mukhamad Najib ${ }^{* *}$, Harianto ${ }^{* * *}$, Bustanul Arifin ${ }^{* * * *}$ \\ ${ }^{*}$ School of Business, IPB University \\ Jl. Pajajaran Bogor 16151, Indonesia \\ ${ }^{* *}$ Department of Management, Faculty of Economics and Management, IPB University \\ Jl. Agatis, IPB Darmaga Campus, Bogor 16680, Indonesia \\ ${ }^{* * *}$ Department of Agribusiness, Faculty of Economics and Management, IPB University \\ Jl. Agatis, IPB Darmaga Campus, Bogor 16680, Indonesia \\ ${ }^{* * * *}$ University of Lampung
}

Prof. Dr. Sumantri Brojonegoro Street No. 1 Bandar Lampung, 35145

\begin{abstract}
Entrepreneurship is faced with the challenges of environmental dynamics in the TUNA era (Turbulence, Uncertainty, Novelty, and Ambiguity). This paper aims to analyze entrepreneurship development models in DKI Jakarta. The data used in this study are primary and secondary data. This study uses a method with an analytical approach, Interpretative Structural Modeling (ISM). The elements and sub-elements in the ISM questionnaire were obtained from discussions with experts, including local government, entrepreneurs, academics, and the community. The output of ISM analysis is the sub-elements' positions in the four quadrants of the diagram and the level structuring based on the follow-up priority. This study found that sub-elements comprised of bank financial institutions (Bank DKI), LPDB, entrepreneurial empowerment volunteers, universities (LPPM), and researchers (lecturers) were included in sector II (dependent). Other sub-elements like DPRD, kasatpel, the business community, non-bank financial institutions, entrepreneurial activists, influential figures, and the public were included in sector III (linkage). There are sub-elements in sector IV (independent), such as governors, mayors/regents, related agencies, business actors, e-commerce, online media, and endorsers. The ISM analysis results show that the sub actor with the highest influence level is the governor. It shows that the governor has a very strategic role in developing entrepreneurship in DKI Jakarta.
\end{abstract}

Keywords: entrepreneur, ISM, entrepreneurship development model, developing entrepreneurship

\begin{abstract}
Abstrak: Kewirausahaan dihadapkan pada tantangan dinamika lingkungan di era TUNA (Turbulensi, Ketidakpastian, Kebaruan, dan Ambiguitas). Tulisan ini bertujuan untuk menganalisis model pengembangan kewirausahaan di DKI Jakarta. Data yang digunakan dalam penelitian ini adalah data primer dan data sekunder. Penelitian ini menggunakan metode dengan pendekatan analitis, Interpretative Structural Modeling (ISM). Unsur-unsur dan sub-unsur dalam kuesioner ISM diperoleh dari diskusi dengan para ahli, termasuk pemerintah daerah, pengusaha, akademisi, dan masyarakat. Output dari analisis ISM adalah posisi sub-elemen pada empat kuadran diagram dan penataan level berdasarkan prioritas tindak lanjut. Studi ini menemukan bahwa sub elemen yang terdiri dari lembaga keuangan bank (Bank DKI), LPDB, relawan pemberdayaan wirausaha, perguruan tinggi (LPPM), dan peneliti (dosen) termasuk dalam sektor II (dependen). Sub elemen lainnya seperti DPRD, kasatpel, dunia usaha, lembaga keuangan non bank, penggiat wirausaha, tokoh berpengaruh, dan masyarakat termasuk dalam sektor III (linkage). Ada sub-elemen di sektor IV (mandiri), seperti gubernur, walikota/bupati, dinas terkait, pelaku usaha, e-commerce, media online, dan endorser. Hasil analisis ISM menunjukkan bahwa sub aktor dengan tingkat pengaruh tertinggi adalah gubernur. Hal ini menunjukkan bahwa peran gubernur sangat strategis dalam mengembangkan kewirausahaan di DKI Jakarta.
\end{abstract}

Kata kunci: wirausaha, ISM, model pengembangan wirausaha, pengembangan wirausaha

\footnotetext{
${ }^{1}$ Corresponding author:

Email: kang.astar@gmail.com
} 


\section{INTRODUCTION}

The global economy is a confluence of risks that could cause significant damage to development prospects in the long term. Indonesia, as a developing country, is faced with a potential economic flush due to global uncertainty. Economic acceleration is no longer focused on improving economic performance but also optimizing human resources. The development of human resources quality is a national strategic agenda. Related to the business climate, the condition of Indonesia's economic competitiveness is showing an improving situation. Based on the Global Competitiveness 4.0 index in 2019, Indonesia ranks 50th overall with 64.6 points, down five places compared to the previous year. This condition shows that Indonesia benefits from its large geographic size and reciprocal relationships combined with a dynamic entrepreneurial culture. The dynamics of entrepreneurial business as a whole can be used as a good momentum to be developed.

Entrepreneurship is one of the business sectors and the most crucial backbone of the country's development. Entrepreneurshippositively correlates with theeconomy, as research conducted by Wennekers and Thurik (1999) showed a correlation between entrepreneurship and economic development. Ranjan (2019) explained that entrepreneurship positively impacts economic growth because it can form capital, generate jobs, improve the standard of living of a country and region, decentralize the distribution of economic resources, and increase the gross national product (GNP).

The definition of entrepreneurship is still developing in line with the complete understanding of entrepreneurial aspects. In the future, the challenges faced will be even more severe, with demands for adjustments to changes amidst uncertainties and technological developments and digitization. Entrepreneurial success is inseparable from a combination of attitudes, resources, and infrastructure known as an entrepreneurial ecosystem. Based on the Global Entrepreneurship Index as an indicator that can see the condition of entrepreneurship in all countries, 14 indicators describe each country's performance related to entrepreneurship. Indonesia is declared left behind other South East Asia countries in internationalization, technology absorption, and human capital (The Global Entrepreneurship and Development Institute). It shows that the development of the entrepreneurial ecosystem in Indonesia has not shown promising results. It is also indicated by the number of entrepreneurs in Indonesia who are still left behind compared to several countries in Southeast Asia. The ratio of entrepreneurs number in Indonesia relative to the population is $3.1 \%$ (Kata Data, 2019).

The opportunity of the Indonesian business climate to support entrepreneurial development is enormous. The most significant contributor in achieving the ease of business in Indonesia at the global level is the DKI Jakarta area. DKI Jakarta is a strategic area for entrepreneurship development. Jakarta is one of the provinces of Indonesia with a relatively good entrepreneurial ecosystem. The World Bank report shows that the ease of doing business in DKI Jakarta is somewhat better than other regions in Indonesia. In addition, the DKI Jakarta economy contribution to the national and GRDP per capita in 2020 is the largest compared to other provinces, each of $17.56 \%$ and IDR168,416,800, respectively (constant prices).

Currently, entrepreneurship development in DKI Jakarta is faced with problems from economic, social, and geopolitical aspects. In the entrepreneurial economic aspect, DKI Jakarta is still faced with limited access to capital. Most small entrepreneurs spend their initial capital from their wallets or informal sources such as loan sharks. Only 7\% rely on initial capital from banks. A similar condition occurs in DKI Jakarta. Major social problems in entrepreneurship development in DKI Jakarta are related to the competence and ability of human resources, the application of entrepreneurship training, and urbanization which encourages people to work and improve their living standards in DKI Jakarta. The geopolitical problems can be seen from the large number of people in DKI Jakarta who do not take advantage of entrepreneurial coaching and development services due to the asymmetry of regulatory information.

One of the efforts to increase entrepreneurship in DKI Jakarta is a collaboration between stakeholders to create thriving and sustainable entrepreneurship, especially in the regions. It is in line with the concept of 4 levels of urban evolution developed by Marcus Foth, namely Socialization, Consultation, Participation, Collaboration. In line with this, Triyowati (2016) explained a correlation between all stakeholders to increase the regional economy. Integration between the roles of local government (politics, transparency, infrastructure providers), NGOs, entrepreneurs, 
and experts, to provide the capital needed by local communities to start a business. Therefore, this paper aims to analyze the entrepreneurship development model in DKI Jakarta primarily based on the perspective of related stakeholders.

\section{METHODS}

The selection of research locations was carried out in DKI Jakarta Province. The data in this study are primary data with an instrument in a questionnaire by the respondent. Respondents of this study are related stakeholders in the field of entrepreneurship. Experts who became respondents in this study consisted of local governments, entrepreneurs, academics, and communities. Expert respondents were selected or determined using a purposive sampling approach. Secondary data were obtained from reports and documents related to regional development, as well as supporting data obtained from literature and internet studies

This study uses a method with an analytical approach, Interpretative Structural Modeling (ISM). The Interpretative Structural Modeling (ISM) approach is used to analyze the actors who are influential in developing regional entrepreneurship with the output in the form of a regional entrepreneurship development model. Warfield invented the ISM method in 1974. This method allows the development of a relationship map between the various elements involved in complex situations. The relationship between elements is depicted in four symbols, namely V, A, X, O. Each of these symbols has a meaning, namely:

$\mathrm{V}$ when element 1 affects element 2 , but not vice versa A when element 2 affects element 1 , but not vice versa $X$ when element 1 and element 2 influence each other $\mathrm{O}$ when element 1 and element 2 do not affect each other

\section{RESULTS}

\section{Actors in Regional Entrepreneurship Development}

Based on the research results, influential actors in developing entrepreneurship include the government, entrepreneurs, information media, communities, academics, financial institutions, entrepreneurial activists, volunteers. In Figure 1, it can be seen that the most influential actor is government, with a percentage of $15 \%$. Other influential actors who have a high percentage are entrepreneurs, the information media, and the community. These results suggest that the government is the leading actor in regional entrepreneurship development, followed by entrepreneurs, information media, and communities who play an essential role in assisting the government. The role of the information media as a companion role can be said to be in the same position as entrepreneurs and the community. The effect of digitalization needs to be considered in the current conditions that are moving dynamically and quickly. Other actors who also play a supporting role in developing regional entrepreneurship are academics, financial institutions, and entrepreneurial activists. The ISM approach begins by defining the elements and sub-elements as a reference in the preparation of the questionnaire. These elements and sub-elements were determined through a discussion process with experts (Table 1).

\section{Government}

The government has a strategic role in the development of regional entrepreneurship. The government plays a vital role in promoting entrepreneurship (Kader et al. 2009). One of the government's tasks is to create a favourable environment for the formation and development of new entrepreneurs (Ahmad et al. 2012). Removing barriers to registration and business administration is one of the efforts that the government can take to create a business environment suitable for entrepreneurial development (Dzafic and Amra, 2016). The central government and governors are considered the main actors influencing the development of regional entrepreneurship. Godlewska and Morawska's (2019) research also shows that provincial and urban governments are influential and more successful in supporting entrepreneurship development.

Government entrepreneurial support also refers to providing much-needed resources in the government's capacity to support and promote entrepreneurship; such as a favourable business environment, funding policies, and simplification of guidelines to remove barriers for emerging entrepreneurs (Obaji and Olugu, 2014). The governments of most developing countries have invested heavily in efforts and resources to promote entrepreneurship (Oni and Daniya, 2012). 


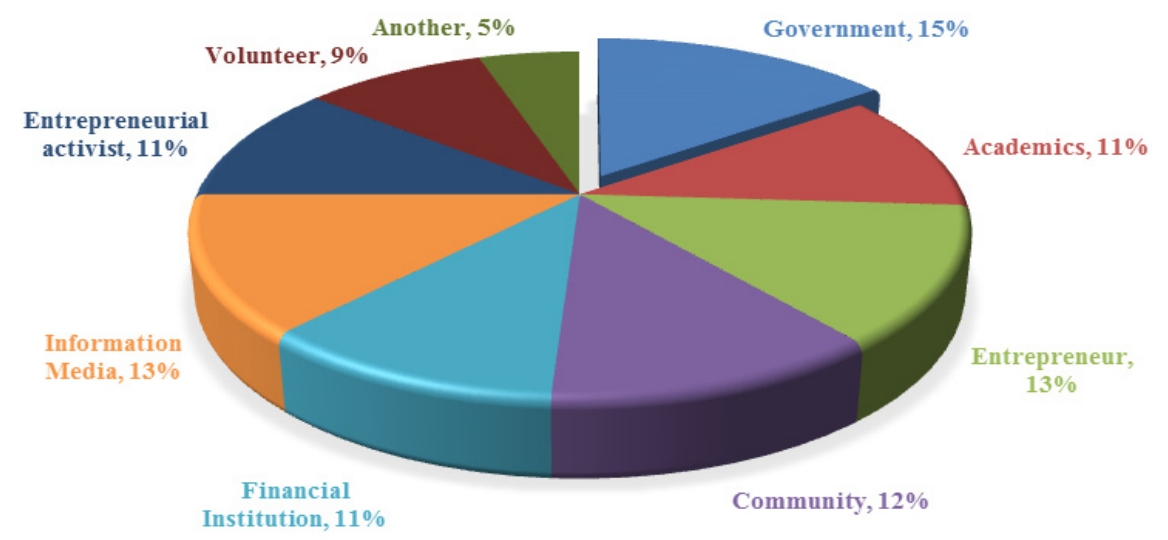

Figure 1. Distribution graph of influential actors in entrepreneurship development

Table 1. Research elements and sub-elements

\begin{tabular}{ll}
\hline Element & Sub-element \\
\hline Government & Central government \\
& Governor \\
& Mayor, Regent \\
& DPRD \\
& Kasatpel \\
& Related agencies \\
Entrepreneur & Entrepreneurs \\
& E-Commerce \\
Media and & Online media \\
information & Endorsers \\
Community & Business community \\
& Organizational associations \\
\hline
\end{tabular}

\section{Information Media}

Digital developments create an environment that is adaptive to change and modernization. The current phenomenon, the information media also influences the development of regional entrepreneurship. The development of information technology has been widely recognized for its important role in encouraging entrepreneurial development for economic performance in developed countries over the last 15 years (Del Giudice and Straub, 2011). Information technology can facilitate the development of microbusinesses in several ways. It serves as an information distribution channel (eg digital information sharing via India's-Choupal) or the product/service itself (eg electronic prepaid cell phone card).

On a larger scale, information technology can also manifest in the form of online platforms that allow the development of online shops by lowering entry

\begin{tabular}{ll}
\hline Element & Sub-element \\
\hline Financial & Bank financial institutions (DKI) \\
institutions & Revolving Fund Management \\
& Institution (LPDB) \\
Entrepreneurial & Non-bank financial institutions \\
Activist & Investors \\
Volunteer/ & Entrepreneurial activist \\
volunteer & Entrepreneurship empowerment \\
& volunteer \\
& Influential figure \\
Academics & Public \\
& Higher Education (LPPM) \\
& Researcher (lecturer) \\
\hline
\end{tabular}

barriers to starting a business (for example Alibaba and Taobao China platforms) (Tan et al. 2016). The growth of digital platforms is currently considered to be the driving force for the rise of entrepreneurship. The majority of respondents consider e-commerce actors as the main actors influencing the development of regional entrepreneurship. Huang et al. (2018) also showed that e-commerce spurs entrepreneurship in urban and rural areas in two ways, encouraging the start of new businesses and reducing the exit of existing businesses from the market. Social media is also used to promote entrepreneurship by entrepreneurs (Samuel and Sarprasatha, 2015). Besides that, the role of other media such as tv, online media, print media and influencers also supports the development of regional entrepreneurship. The research of Hindle and Klyver (2006) shows that mass media publication about successful entrepreneurship has a positive correlation with the number of new entrepreneurs. 


\section{Entrepreneur}

The role of entrepreneurs or business actors in entrepreneurship development is important. The survival of a business in an unpredictable environment depends on the entrepreneurship and leadership competencies of its owners/managers, combined with their talents, energy and skills (Demartini and Beretta, 2020; Huang et al. 2014; Paudel, 2019). Various literature shows that entrepreneurial leaders need to have relevant experience and skills (Chen, 2007), especially interpersonal skills (Watson et al. 1995), creativity (Amabile, 1997), and opportunity orientation (Ardichvili et al. 2003), which can help them formulate the desired image of the future, inspire other employees to follow their vision. Several pieces of research showed that entrepreneurship capabilities and competencies can lead to superior performance (Bamiatzi et al. 2015; Cogliser dan Brigham, 2004; Fontana dan Musa, 2017; Gupta et al. 2004; Ireland et al. 2003; Koryak et al. 2015).

\section{Community}

Social Capital Theory (community) is a theoretical perspective that shows the actual and potential resources embedded in, available through, and originating from the network of relationships that are owned by individuals or social units (Nahapiet and Ghoshal, 1998). Community is considered as one of the social capitals that can increase the efficiency of actions, such as the dissemination of information, in networks characterized by weak ties or structural holes. Communities as a formal institution of growing stakeholders that are bound together by common interests in potential opportunities and serve important evaluations in entrepreneurship (Autio et al. 2013).

The community supports entrepreneurship not only at the functional level (such as access to capital to banks) but also at the relational level (Fortunato and Alter, 2015). In entrepreneurship studies, social (community) capital influences an entrepreneur's ability to achieve success (Kim and Aldrich, 2005). Social capital is a supporting factor needed to encourage entrepreneurship, especially in the agricultural community (Adhikari et al. 2018). Social capital provides a social network for entrepreneurs that facilitates recognition and creation of entrepreneurial opportunities as well as the identification, collection and allocation of scarce resources (Stam and Elfring, 2008).

\section{Academics}

Education is one part of social factors that significantly affect regional entrepreneurial activity (Lugo and Espina, 2014). One of the actors in the field of education is academics. As someone who has received higher education, academics can have an impact on the level of motivation of the community to become entrepreneurs (Pangestu et al. 2014). This motivation is very important to encourage someone to become an entrepreneur.

In today's knowledge-based society, universities are increasingly engaged in outreach activities that go beyond teaching and research (Ardito et al. 2019; Rinaldi et al. 2018; Trencher et al. 2014). In this regard, universities begin to become more open to society, carrying out various types of activities (for example, knowledge dissemination, technological innovation, social innovation, consulting services, or entrepreneurship), with government support or not, at the local, regional, or regional level or global (Guerrero et al. 2016a). The contribution of universities to social and economic progress should not be limited to capitalization of knowledge (Etz-kowitz, 2004) as universities can act as local agents to stimulate entrepreneurial capital (Audretsch 2014; Guerrero and Urbano, 2012) by promoting entrepreneurial thinking, action, and institutions(Guerreroetal.2016a). Therefore, universities are considered as transformational agents capable of enhancing entrepreneurial capabilities, driving ecosystem change, and catalyzing natural or financial resources in certain environments (Klofsten and Jones-Evans, 2000; Siegel and Wright, 2015).

\section{Financial Institutions}

Access to finance for entrepreneurs is very important. Access to financial institutions in business development is carried out to increase opportunities to expand the scope of business being carried out. Bowen and De Clercq (2008) show that the allocation of business resources for high growth activities is positively related to financing. A competitive country is a country that looks at existing financial resources and considers the most effective means of deployment to reverse the desired positive effects. Therefore, a competitive country seeks to understand how existing financial resources may best be used to produce the desired positive effects, generating both welfare and public services and overall economic development. 
Bank financial institutions are the main actors supported by non-bank financial institutions and finance companies. The Indian government has set up several financial institutions that can provide the financial assistance needed by entrepreneurs to run their businesses (Sant, 2014). Several studies have shown that finance has a positive impact on entrepreneurship as shown by how good governance affects entrepreneurship in developing countries. More flexible banking procedures to accommodate entrepreneurial activities and easily available credit facilities with predetermined schemes are very important in regional entrepreneurship development. Financing institutions not only provide financial support in the form of money but also assistance for equipment, raw materials, equipment rental to training (Sarumathi, 2019). However, the government also needs to pay attention that people's incentives to entrepreneurship will decrease if government intervention is too high in public funding (Bjornkov and Foss, 2006).

\section{Volunteer}

Local social networks based on trust can help spread knowledge and best practices among entrepreneurs, as well as pool them with valuable resources (Aldrich and Martinez, 2007; Dacin et al. 2010; van Rijnsoever, 2020). Within the entrepreneurial ecosystem, there is a strong social network for sustainable entrepreneurship. Social entrepreneurship and innovation are also highly valued in less contemporary urban governance, especially in Europe (Brandsen et al. 2016). The European Commission, for example, has positioned social entrepreneurship and innovation at the centre of creating and realizing new opportunities in cities to tackle longstanding social and ecological problems amid disinvestment in public and community services. Note that the 'social' which is entrepreneurial goal is a form of collective actions and the participatory notion of participatory associations (Moulaert et al. 2013), but it is the domain of collective urban problems to be gradually acted upon in creative and innovative ways. The survey results show that volunteers influence the development of regional entrepreneurship. Although the influence is not as big as other actors, volunteers are seen as social entrepreneurship capable of creating sustainability. Social entrepreneurship and innovation are also highly valued in less contemporary urban governance, especially in Europe (Brandsen et al. 2016).

\section{Entrepreneurial Activist}

Entrepreneurial activists focus on the sustainability of a business activity carried out by entrepreneurs. Various movements that plan to build a business are carried out by entrepreneurial activists. Therefore, entrepreneurial activists consider carefully expanding the appeal of the movement being carried out. The survey results show that entrepreneurial activists influence the development of regional entrepreneurship. Business activists can encourage sustainability in the entrepreneurial process. Entrepreneurial activists are important in creating the ability to think creatively about incorporating views into innovations. Entrepreneurial activists have a very strong view of the problems and challenges ahead, so it needs special efforts for business activists, especially in developing entrepreneurship in the regions.

\section{Entrepreneurship Development Model in DKI Jakarta}

The result of the research based on the ISM analysis approach examines the interaction of the sub-elements of the actors who influence the development of regional entrepreneurship. The interaction of these subelements then becomes the basis for entrepreneurship development models in DKI Jakarta. After obtaining the SSIM -VAXO matrix, then transformed into the Reachability Matrix (RM). RM is the conversion of the relationship notation $\mathrm{A}, \mathrm{V}, \mathrm{X}$ and $\mathrm{O}$ from the SSIM matrix into binary form with rule 1 , which means that criteria $\mathrm{I}$ affect the criteria $\mathrm{J}$ and 0 which means that criteria I do not affect the criteria J.

The results of the ISM analysis are in the form of a mapping of the reachability matrix based on the driver power (DP) and dependence (D). The purpose of mapping is to determine the position of the subelement resulting from the combination of the two values attached to it as in Figure 2.

The results of the mapping show that the subelements including central government, bank financial institutions (Bank DKI), LPDB, public, entrepreneurial empowerment volunteers, universities (LPPM)) are included in sector II (dependent), which means that these sub-elements have a weak driving force and high dependence. While the sub-elements of DPRD, Kasatpel, researcher, the business community, organizational associations, non-bank financial institutions, entrepreneurial activists, influential figures 
and the community are included in sector III (linkage), meaning that these sub-elements have a strong driving force and high dependence.

Finally, in sector IV (independent) there are subelements of the governor, mayor/regent, related agencies, business actors, e-commerce, online media and endorsers. This sector has the highest driving power value with the smallest dependence value compared to other sub-elements. This shows that this sub-element is a key factor in the development of entrepreneurship in DKI Jakarta because it has a very strong driving force with a high degree of independence (not influenced by other factors).

Figure 3 shows the results of the level structuring of the sub-elements in this study. These results indicate that level-1 to level-4 are the sub-elements that become the main priority in entrepreneurship development in DKI Jakarta. In priority, the sub-elements in question are governors, related agencies, investors, business actors, endorsers, mayors \& regents, e-commerce and online media. The next priority is level 5 , namely the sub-elements of the DPRD, Kasatpel, the business community, organizational associations, non-bank financial institutions, entrepreneurial activists, influential figures and researchers. While the last priority or that has relatively little influence in entrepreneurship development is at level 6 - level 8 . The sub-elements in this last priority are the community, central government, universities, bank financial institutions. Modelling results using the ISM approach show that the governor has influenced related agencies and investors. This shows that the governor has a strategic role in developing entrepreneurship in DKI Jakarta.

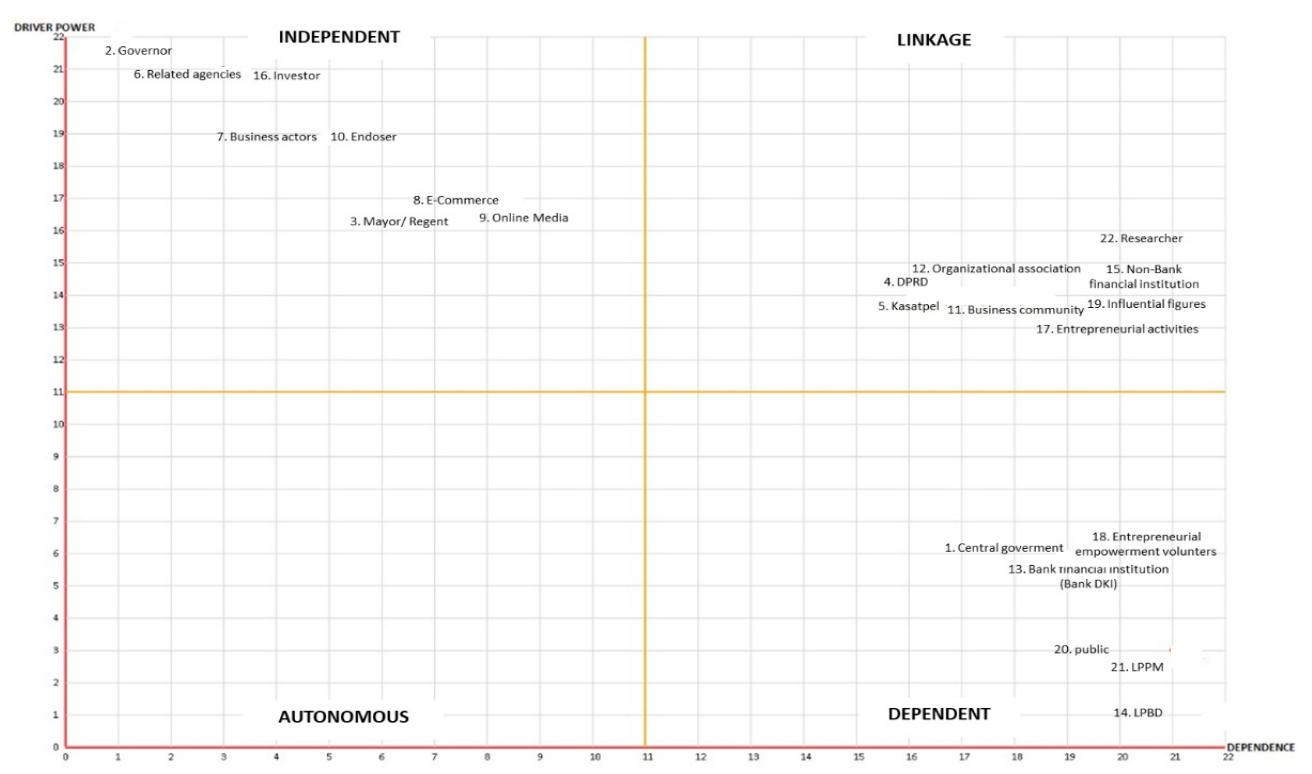

Figure 2. Quadrant/sector mapping of sub-elements

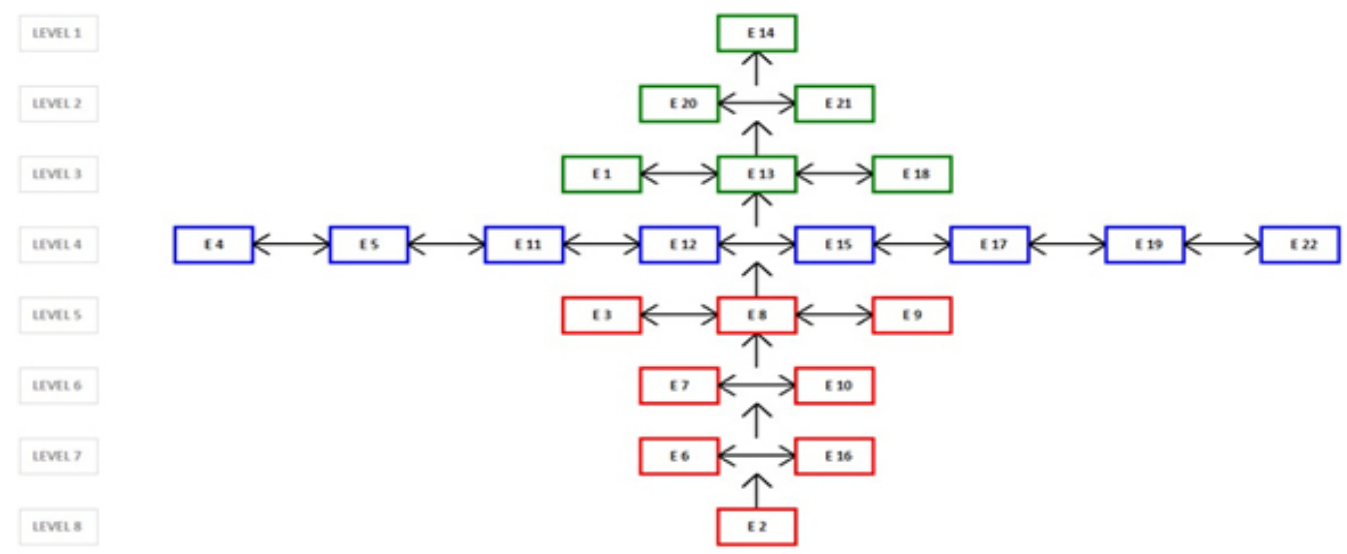

Figure 3. Mapping the structure of the sub-element level 


\section{Managerial Implications}

The entrepreneurship development model for the DKI Jakarta area that is formed can develop the potential for skills and sustainable business independence through collaborative efforts between stakeholders from the local government, business world, community and academia. There is a regional entrepreneurship development model for DKI Jakarta, so the roles and functions of each stakeholder are clearly stated in each corridor (leading to technical) so that there is no overlapping of programs, differences in data and competition for business actors. In addition, targeting in the regional entrepreneurship development model in DKI Jakarta is no longer focused on groups but individuals or people gathered in groups. This is because in entrepreneurship development there is a mentoring process, which allows individuals to have different levels or levels of entrepreneurship. This condition has the impact of not only providing opportunities to get business opportunities and starting new businesses but will provide opportunities for all individuals to create new businesses

\section{CONCLUSIONS AND RECOMMENDATIONS}

\section{Conclusions}

The results showed that 8 actors have strong interactions with entrepreneurship development in DKI Jakarta. The eight actors are government, entrepreneurs, media and information, communities, financial institutions, entrepreneurial activists, volunteers and academics. The eight actors were later revealed to be 22 sub actors. The ISM analysis results show the sub-element has a weak driving force and high dependence (dependent) are central government, bank financial institution (Bank DKI), LPDB, Public, Entrepreneurial empowerment volunteers and University. The sub-element has a strong driving force and high dependence (linkage) are DPRD, Kasatpel, researcher, the business community, organizational associations, non-bank financial institutions, entrepreneurial activists, influential figures and the community. And, sub-element has the highest driving power value with the smallest dependence value (independent) are the governor, mayor/regent, related agencies, business actors, e-commerce, online media and endorsers. The sub actor who has the highest level of influence is the governor. This shows that the governor has a very strategic role in developing entrepreneurship in DKI Jakarta.

\section{Recommendations}

The governor is an actor who has a strong role in the development of entrepreneurship in DKI Jakarta, therefore a policy is needed that ensures the sustainability of entrepreneurship development in DKI Jakarta, regardless of the governor. The need for institutional strengthening and collaboration between actors, so that the Entrepreneurship Development model in DKI Jakarta can be implemented properly. Further research can be carried out by analyzing a collaborative entrepreneurial ecosystem model that connects actors who have an important role in entrepreneurship development with the dimensions that make up the entrepreneurial ecosystem to create an independent and sustainable regional entrepreneurship development.

\section{REFERENCES}

Adhikari RP, Bonney L, Woods M, Clark S, Coates L, Harwood A, Eversole R, Miles MP. 2018. Applying a community entrepreneurship development framework to rural regional development. Small Enterprise Research 25(3):1-19.

Ahmad AR, Yusoff WFW, Noor HM, Ramin AK. 2012. Preliminary study of rural entrepreneurship development program in Malaysia. Journal of Global Entrepreneurship Research 2(1):1-8.

Amabile TM. 1997. Motivating creativity in organizations: On doing what you love and loving what you do. California Management Review 40(1):39-58.

Aldrich HE, Martinez MA. 2007. Many are called, but few are chosen: An evolutionary perspective. Entrepreneurship Theory and Practice 25(4):4156.

Ardichvili A, Cardozo R, Ray S. 2003. A theory of entrepreneurial opportunity identification and development. Journal of Business Venturing 18(1):105-123. 
Audretsch DB, Beckmann IAM. 2007. From Small Business to Entrepreneurship Policy. Audretsch DB, Grilo I, Thurik R, Handbook of Research on Entrepreneurship, editor. Cheltenham: Edward Elgar Publishing.

Autio E, Kenney M, Mustar P, Siegel DS, Wright M. 2014. Entrepreneurial innovation: the importance of context. Research Policy 43:1097-1108.

Bamiatzi V, Jones S, Mitchelmore S, Nikolopoulos K. 2015. The role of competencies in shaping the leadership style of female entrepreneurs: The case of North West of England, Yorkshire, and North Wales. Journal of Small Business Management 53(3):627-644.

Bjornskov C, Foss N. 2006. Economic freedom and entrepreneurial activity: Some cross-country evidence. Public Choice 134(3):307-328.

Brandsen T, Evers A, Cattacin S, Zimmer A. 2016. Social Innovation: A Sympathetic and Critical Interpretation. In T. Brandsen, A. Evers, S. Cattacin, \& A. Zimmer (Eds.), Social innovations in the urban context. Heidelberg: Springer Open.

Chen MH. 2007. Entrepreneurial leadership and new ventures: Creativity entrepreneurial teams. Creativity and Innovation Management 16(3):239-249.

Cogliser CC, Brigham KH. 2004. The intersection of leadership and entrepreneurship: Mutual lessons to be learned. The Leadership Quarterly 15(6):771-799.

Del Giudice M, Straub D. 2011. Editor's comments -IT and entrepreneurism: An on-again, off-again love affair or a marriage?. MIS Quarterly 35(4):3-8.

Demartini MC, Beretta V. 2020. Intellectual capital and SMEs' performance: A structured literature review. Journal of Small Business Management 58(2):288-332.

Dzafic Z, Babajic A. 2016 The role of the government in entrepreneurship development: Evidence from Bosnia and Herzegovina. Journal of Economics and Business 14(1):68-79.

Etzkowitz H. 2003. Innovation in innovation: the triple helix of university-industry-government relations. Social Science Information 42(3):293337.

Fontana A, Musa S. 2017. The impact of entrepreneurial leadership on innovation management and its measurement validation. International Journal of Innovation Science 9(1):2-19.

Fortunato MWP, Alter T. 2015. Community entrepreneurship development: an introduction. Community Development 46(5):444-455.

Gupta V, MacMillan IC, Surie G. 2004. Entrepreneurial leadership: Developing and measuring a crosscultural construct. Journal of Business Venturing 19(2):241-260.

Godlewska M, Morawska S. 2019. Development of local and regional entrepreneurship-which institutions matter? Evidence from Poland. Economic Research 33(1):1017-1035.

Guerrero M, Urbano D. 2014. Academics' start-up intentions and knowledge filters: an individual perspective of the knowledge spillover theory of entrepreneurship. Small Business Economics 43(1):57-74.

Hindle K, Klyver K. 2007. Exploring the relationship between media coverage and participation in entrepreneurship: Initial global evidence and research implications. International Entrepreneurship and Management Journal 3(2):217-242.

Huang B, Shaban M, Song Q, dan Wu Y. 2018. E-commerce development and entrepreneurship in the people's Republic of China. ADBI Working Paper 827.

Kader RA, Mohamad MRB, Ibrahim AAHC. 2009. Success factors for small rural entrepreneurs under the one district one industry programme in Malaysia. Contemporary Management Research 5(2):147-162.

Kata Data. 2019. Peringkat kewirausahaan Indonesia nomor dua terendah di ASEAN. https://databoks. katadata.co.id/datapublish/2019/10/04/ peringkat-kewirausahaan-indonesia-nomor-duaterendah-di-asean. [10 April 2020].

Klofsten M, Jones-Evans D. 2000. Comparing academic entrepreneurship in Europe-the case of Sweden and Ireland. Small Business Economics 14(4):299-309.

Lugo JE, Espina MI. 2014. Determinant factors for the development of entrepreneurial activity: A correlational study. Esic Market Economics and Business Journal 45(1):147-160.

Moulaert F, MacCallum D, Mehmood A, Hamdouch A. 2013. General introduction: The return of social innovation as a scientific concept and a social practice. Stanford Social Innovation Review 38-43.

Nahapiet J, Ghoshal S. 1998. Social capital, intellectual capital and organizational advantage. Academy of Management Review 23(2):242-266. 
Obaji NO, Olugu MU. 2014. The role of government policy in entrepreneurship development. Science Journal of Business and Management 1(4): 109115.

Oni EO, Daniya A. 2012. Development of small and medium scale enterprises: the role of government and other financial institutions. Arabian Journal of Business and Management Review 1(7):1629.

Pangestu G, Nicky, Fuston P, Kumar MS. 2014. Factors that affect the entrepreneurs' growth in Bekasi Region, Indonesia. International Journal of Scientific and Research Publications 4(1):1-8.

Ranjan A. 2019. The role of entrepreneurship in economic development. American Journal of Management Science and Engineering 4(6):8790.

Samuel BS, Sarprasatha J. 2015. Social media as a factor for promoting entrepreneurship-the Middle East \& Oman scenario. International Journal of Economics, Finance, and Management Sciences 3(5):483-493.

Sant RK. 2014. Role of financial institutions in entrepreneurial development with special reference to woman entrepreneurs. Scholarly Research Journal for Interdisciplinary Studies
2(10):1023-1031.

Sarumathi I. 2019. A study on the role of government and financial institutions in entrepreneurial development. Shanlax International Journal of Commerce 7(2):1-6.

Trencher G, Yarime M, McCormick KB, Doll CNH, Kraines SB. 2014. Beyond the third mission: exploring the emerging university function of co-creation for sustainability. Sci Public Policy 41(2):151-179.

Triyowati H. 2016. The mapping of local economic development in decentralized governance era. Business and Entrepreneurial Review 11(1):6792.

Watson WE, Ponthieu LD, Critelli JW. 1995. Team interpersonal process effectiveness in venture partnerships and its connection to perceived success. Journal of Business Venturing 10(5):393-411.

Wennekers S, Thurik R. 1999. Linking entrepreneurship and economic growth. Journal Small Business Economic 13:27-55.

World Bank. 2019. Persentase Pemuda Asia Tenggara yang Ingin Jadi Pengusaha. Washington: World Bank. 